\title{
Kajian Layanan Perbankan Syariah Dalam Menciptakan Kepuasan Nasabah Penyimpan Dalam Upaya Mengoptimalkan Kondisi Likuiditas
}

\author{
Lely Savitri Dewi \\ Institut Manajemen Koperasi Indonesia \\ lelysavitridewi@yahoo.com
}

\begin{abstract}
ABSTRAK
Lahirnya Undang-Undang Republik Indonesia No. 10 tahun 1998 tentang Perubahan Undang-Undang Republik Indonesia No. 7 tahun 1992 tentang Perbankan telah memberikan peluang yang sangat besar bagi tumbuhnya bank-bank syariah di Indonesia baik Bank Umum syariah maupun Bank Perkreditan Rakyat Syariah. Akan tetapi yang disayangkan dalam hal ini adalah tidak semua masyarakat memahami dan menyadari tentang seluk beluk praktek perbankan syariah tersebut, sehingga bank-bank syariah masih tetap harus gencar lagi dalam melakukan sosialisasi dan promosi kepada seluruh kalangan masyarakat supaya mampu bersaing dengan bankbank konvensional khususnya yang melakukan pengembangan bisnisnya dengan membuka Unit Usaha Syariah (UUS). Dalam hal penghimpunan dana bank, secara umum perbankan mengandalkan dana pihak ketiga dari nasabah untuk menopang kegiatan penyaluran dana. Terkait hal tersebut tentunya pelayanan bank terhadap nasabah terutama dalam kegiatan penyimpanan dana manajemen harus sangat memprioritaskan kepuasan nasabah agar selalu termotivasi untuk menitipkan dananya di bank, sehingga mobilisasi dana pihak ketiga mampu mengimbangi penyaluran dana yang optimal pada akhirnya akan meningkatkan kinerja likuiditas nya melalui indikator Finance to Deposits Ratio ( FDR ). FDR ini digunakan untuk melihat seberapa jauh pembiayaan kepada nasabah dapat mengimbangi kewajiban untuk segera memenuhi hutang jangka pendeknya kepada nasabah yang ingin menarik kembali uangnya yang telah digunakan oleh bank untuk melihat kemampuan dan kerawanan dari suatu bank
\end{abstract}

Kata kunci : perbankan syariah, pelayanan bank, kepuasan nasabah, likuiditas (FDR)

\section{ABSTRACT}

The Birth of the Law of the Republic of Indonesia No. 10 of 1998 concerning Amendments to the Law of the Republic of Indonesia No. 7 of 1992 concerning Banking has provided a huge opportunity for the growth of Islamic banks in Indonesia, both Sharia Commercial Banks and Sharia People's Credit Banks. However, what is unfortunate in this case is that not all people understand and are aware of the ins and outs of Islamic banking practices, so that Islamic banks still have to be vigorous again in conducting socialization and promotion to all people in order to be able to compete with conventional banks in particular who do business development by opening a Sharia Business Unit (SBU). In terms of raising bank funds, banks generally rely on third party funds from customers to support fund distribution activities. Related to this, of course, bank services to customers, especially in fund management activities, must prioritize customer satisfaction so that they are always motivated to deposit their funds in the bank, so that third party fund mobilization is able to compensate for optimal fund distribution which will ultimately improve its liquidity performance through the Finance to Deposits Ratio (FDR). This FDR is used to see how far financing to customers can offset the obligation to immediately meet its short-term debt to customers who want to withdraw their money that has been used by the bank to see the ability and vulnerability of a bank

Keywords: Islamic banking, bank services, customer satisfaction, liquidity (FDR)

\section{PENDAHULUAN}

Penggolongan Bank berdasarkan UU RI No 10 tahun 1998 tentang Perbankan terdiri dari Bank Umum dan Bank Perkreditan Rakyat. Dalam kegiatan usahanya berlandaskan syariah terdapat
Bank Umum Syariah dan Bank Perkreditan Rakyat Syariah (BPRS).

Istilah BPRS bukan lagi menjadi suatu hal yang baru bagi masyarakat. BPRS adalah salah satu lembaga keuangan perbankan syariah yang pola 
operasionalnya mengikuti prinsip-prinsip muamalah Islam. Fungsi Bank Pembiayaan Rakyat Syariah secara garis besar tidak berbeda dengan jenis BPR lainnya, yakni sebagai lembaga intermediasi yang mengerahkan dana dari masyarakat dan menyalurkan kembali dana-dana tersebut kepada masyarakat yang membutuhkannya dalam bentuk fasilitas pembiayaan. Perbedaan pokoknya terletak dalam jenis keuntungan yang diambil bank dari transaksi-transaksi yang dilakukannya. Bila bank konvensional mendasarkan keuntungannya dari pengambilan bunga, maka Bank Pembiayaan Rakyat Syariah mengambil keuntungan dari yang disebut sebagai imbalan, berupa bagi hasil (Loss and Profit Sharing) dan bonus. Berdasarkan jenis operasionalnya, produk Bank Pembiayaan Rakyat Syariah yaitu mobilisasi dana (funding), dan produk penyaluran dana (financing) .

Kepercayaan (trust) yang dimiliki oleh masyarakat terhadap produk dan pelayanan yang ditawarkan oleh Bank Pembiayaan Rakyat Syariah dapat diukur dari seberapa besar perkembangan dana nasabah yang terserap pada bank tersebut, Berikut beberapa kondisi yang menunjukkan hal tersebut:

Jika dilihat dari jumlah rekening, pertumbuhan BPRS di Indonesia sejak 2014 mengalami peningkatan, perkembangannya dapat dilihat dari tabel 1 di bawah ini :

Tabel 1. Pertumbuhan Jumlah Rekening di BPRS

\begin{tabular}{crc}
\hline Tahun & Rekening & $\begin{array}{c}\text { Pertumbuhan } \\
(\boldsymbol{\%})\end{array}$ \\
2014 & 907.775 & - \\
2015 & 1.021 .776 & 12,56 \\
2016 & 1.163 .287 & 13,58 \\
\hline Sumber : www.ojk.go.id & \\
\hline
\end{tabular}

Tingkat pertumbuhan rekening pada tahun 2015 sebesar 12,56\% dan pada tahun 2016 pertumbuhannya sebesar $13,85 \%$. Hal ini menunjukkan bahwa masyarakat telah memiliki trust tersendiri terhadap apa yang diberikan oleh Bank Pembiayaan Rakyat Syariah. Hal ini pula berdampak pada peningkatan volume usaha yang dilakukan BPRS yaitu meningkat sebesar $17,74 \%$ dibanding tahun sebelumnya. Dana yang dihimpun tumbuh sebesar $19,20 \%$, begitu pula pembiayaan yang diberikan tumbuh $15,2 \%$.

Salah satu BPRS yang beroperasi di wilayah Jawa Barat adalah BPRS AL Ma'soem yang terletak di daerah Rancaekek Kabupaten Bandung. Dari kondisi persaingan daerah tersebut sudah banyak berdiri bank-bank baik Bank Umum Konvensional maupun Bank Umum Syariah. Dengan demikian BPRS Al Ma'soem di tuntut harus mampu bersaing dengan bank-bank tersebut dalam rangka mempertahankan nasabah sebagai mitranya dan meningkatkan minat masyarakat sekitarnya untuk memanfaatkan berbagai produk yang ada di BPRS Al Ma'soem.

BPRS Al Ma'soem menyediakan berbagai bentuk kebutuhan nasabah mulai dari produk pembiayaan, produk investasi, produk simpanan, dan jasa-jasa perbankan lainnya. Hal tersebut merupakan bentuk fasilitas yang diberikan oleh BPRS Al Ma'soem kepada para nasabahnya. Dengan menyediakan apa yang butuhkan nasabah maka nasabah akan merasa puas. Nasabah yang puas adalah penyebar informasi yang baik. Kepuasan nasabah sangat berpengaruh positif terhadap kegiatan yang dilakukan oleh BPRS Al Masoem baik dalam kegiatan mobilisasi dana (funding), maupun pembiayaan (finance). Untuk melihat pertumbuhan dana pihak ketiga dan pembiayaan dari tahun 2014-2018 dapat dilihat pada tabel berikut :

Tabel 2. Pertumbuhan dana pihak ketiga BPRS Al Masoem 2014-2018 (dalam ribuan Rp)

\begin{tabular}{ccc}
\hline Tahun & $\begin{array}{c}\text { Dana Pihak } \\
\text { Ketiga }(\mathbf{R p})\end{array}$ & $\begin{array}{c}\text { Pertumbuhan } \\
(\mathbf{\%})\end{array}$ \\
$\mathbf{2 0 1 4}$ & $\mathbf{7 5 . 8 7 4 . 5 5 6}$ & - \\
2015 & 92.295 .371 & 21,64 \\
2016 & 118.331 .068 & 28,21 \\
2017 & 128.958 .632 & 8,98 \\
Maret 2018 & 141.864 .186 & 10,00 \\
\hline \multicolumn{2}{l}{ Sumber : Buku tahunan BPRS Al Ma'soem }
\end{tabular}

Tabel 3 Pertumbuhan pembiayaan BPRS Al Masoem 2014-2018 (dalam ribuan Rp)

\begin{tabular}{ccc}
\hline Tahun & $\begin{array}{c}\text { Pembiayaan } \\
(\mathbf{R p})\end{array}$ & $\begin{array}{c}\text { Pertumbuhan } \\
(\boldsymbol{\%})\end{array}$ \\
2014 & 86.020 .707 & - \\
2015 & 110.563 .192 & 28,42 \\
2016 & 141.703 .408 & 28,17 \\
2017 & 146.819 .052 & 3.61 \\
Maret 2018 & 144.615 .385 & $(15.00)$ \\
\hline Sumber : Buku tahunan BPS Al Ma'soem &
\end{tabular}

Dilihat dari tabel pertumbuhan DPK dan Pembiayaan di atas dapat diketahui bahwa pertumbuhan volume dana pihak ketiga dan volume pembiayaan pada tahun terakhir per Maret 2018 mengalami penurunan yang cukup signifikan. 
Sukses tidaknya bank melakukan fungsi penghimpunan dan penyaluran dana dapat dikaji dari capaian likuiditas .Salah satu rasio yang dapat digunakan untuk mengukur likuiditas suatu bank syariah adalah Financing to Deposit Ratio (FDR). Mengenai keadaan FDR di BPRS Al Ma'soem dari tahun 2014-2018 dapat dilihat pada tabel di bawah ini:

Tabel 4. Keadaan Financing to Deposit Ratio (FDR) BPRS Al Ma'soem tahun 2014-2018 (dalam ribuan $\mathrm{Rp}$ )

\begin{tabular}{lccc}
\hline Tahun & $\begin{array}{c}\text { Pembiayaan } \\
\text { yang } \\
\text { diberikan } \\
\text { (Rp) }\end{array}$ & $\begin{array}{c}\text { Uraian } \\
\text { Dana Pihak } \\
\text { Ketiga yang } \\
\text { diterima } \\
\text { (dalam Rp) }\end{array}$ & $\begin{array}{c}\text { Financing to } \\
\text { Deposit Ratio } \\
\text { (FDR) } \\
\text { (dalam \%) }\end{array}$ \\
\hline 2014 & 86.020 .707 & 75.874 .556 & 113,37 \\
2015 & 110.563 .192 & 92.295 .371 & 119,79 \\
2016 & 141.603 .408 & 118.331 .068 & 119,67 \\
2017 & 146.819 .052 & 128.958 .632 & 115,40 \\
Maret 2018 & 144.615 .385 & 141.864 .186 & 101,93 \\
\hline Sumber : Laporan tahunan BPRS Al Ma'soem
\end{tabular}

Dari tabel di atas rasio Financing to Deposit Ratio (FDR) pada BPRS Al Ma'soem mengalami penurunan secara kualitas Dimana pada tahun 2014 sebesar 113,37\% tahun 2015 sebesar 119,79\%, pada tahun 2016 sebesar 119,67\%. Pada tahun 2017 sebesar 115,40\% dan per Maret 2018 penurunannya cukup drastis yaitu 101,93\% dari sisi FDR hal ini menunjukkan kondisi BPR tidak cukup ekspansif dibanding tahun sebelumnya.

Berdasarkan Surat Edaran Bank Indonesia No. 12/11/DPNF/2010, besarnya FDR yang mencerminkan likuiditas suatu bank yang sehat adalah 80-110\%. Apabila Financing to Deposit Ratio (FDR) suatu bank berada di atas ini ditetapkan oleh Bank Indonesia tidak boleh melebihi $110 \%$. Itu artinya bank boleh memberikan kredit atau pembiayaan melebihi jumlah dana pihak ketiga yang berhasil dihimpun asalkan tidak melebihi $110 \%$. Jadi, besarnya Financing to Deposit Ratio (FDR) yang diijinkan adalah $80-110 \%$.

Berdasarkan kondisi tabel Financing to Deposit Ratio (FDR) tersebut peneliti menduga BPRS mengalami over ekspansif dalam penyaluran dana, karena secara rata-rata capaian Financing to Deposit Ratio (FDR) pada lima tahun terakhir sebesar 114, $032 \%$ artinya BPRS harus selektif dalam kegiatan penyaluran pembiayaan agar likuiditas dana pihak ketiga terjamin. Dalam hal penghimpunan dana bank, secara umum perbankan mengandalkan dana pihak ketiga dari nasabah untuk menopang kegiatan penyaluran dana. Terkait hal tersebut tentunya pelayanan bank terhadap nasabah terutama dalam kegiatan penyimpanan dana manajemen harus sangat memprioritaskan kepuasan nasabah agar selalu termotivasi untuk menitipkan dananya di bank, sehingga mobilisasi dana pihak ketiga mampu mengimbangi penyaluran dana yang optimal pada akhirnya akan meningkatkan kinerja BPRS.

Berdasarkan kondisi terakhir tahun 2018 diperlukan penelitian untuk mengukur layanan kerja perbankan agar mobilisasi dana nasabah dapat lebih optimal , dengan penelitian yang berjudul

"Kajian layanan Perbankan syariah dalam menciptakan kepuasan nasabah penyimpan dalam upaya mengoptimalkan kondisi likuiditas “

Berdasarkan uraian pada latar belakang yang sudah dikemukan diatas, maka dapat dirumuskan masalah sebagai berikut :

1. Sejauhmana layanan bank ditinjau dari kepuasan nasabah dalam menyimpan dana di BPRS Al Ma'soem

2. Upaya apa yang harus dilakukan bank dalam mempertahankan kinerja likuiditas dari sudut Financing to Deposit Ratio (FDR)

\section{KAJIAN TEORITIS}

Lembaga keuangan adalah setiap perusahaan yang bergerak di bidang keuangan di mana kegiatannya hanya menghimpun dana atau hanya menyalurkan dana atau kedua-duanya (Dahlan Siamat, 2005:9). Sedangkan, lembaga keuangan atau financial institution merupakan suatu badan usaha atau institusi kekayaan terutama dalam bentuk assetasset keuangan (financial assets) maupun nonfinancial assets riil (Ahmad, 2007:67).

Lembaga keuangan juga menawarkan bermacam-macam jasa keuangan mulai dan perlindungan asuransi, menjual program pensiun sampai dengan penyimpanan barang-barang berharga dan penyediaan suatu mekanisme untuk pembayaran dana dan transfer dana. Proses transfer dana yang terjadi antara pihak yang kelebihan dana (surplus unit) kepada pihak yang membutuhkan dana (defisit unit) pada umumnya sangat memerlukan perantara atau mediator lembaga keuangan. Proses intermediasi tersebut memberikan dua manfaat yaitu :

1. Memberikan kesempatan kepada pihak surplus unit untuk menanamkan dananya dan memperoleh keuntungan, sehingga membantu memobilisasi dana supaya tidak menganggur.

2. Proses tersebut akan memindahkan resiko surplus unit kepada defisit unit jadi keberadaan 
lembaga keuangan tersebut dimaksudkan agar proses alokasi atau transfer dana berjalan lebih efisien.

Menurut Kasmir (2012:24) bentuk atau jenis lembaga keuangan di Indonesia dibedakan dalam dua jenis, yaitu :

1. Lembaga Keuangan Bank

2. Lembaga Keuangan Non Bank

Menurut Undang-Undang Republik Indonesia No. 10 Tahun 1998 tentang Perbankan Pasal 1 menyatakan bahwa :

"Perbankan adalah segala segala sesuatu yang menyangkut tentang bank, mencakup kelembagaan, kegiatan usaha, serta cara dan proses dalam melakukan kegiatan usahanya"

Istilah bank berasal dari bahasa Italia yaitu banco (bangku), bangku inilah yang digunakan oleh banker untuk melayani kegiatan operasionalnya kepada para nasabah, istilah bangku kemudian berkembang dan populer menjadi bank.

Menurut Kasmir (2003:11) mengenai definisi bank yaitu :

"Bank adalah lembaga keuangan yang kegiatan utamanya adalah menghimpun dana dari masyarakat dan menyalurkan kembali dana tersebut kepada masyarakat serta memberikan jasa bank lainnya."

Kemudian menurut Malayu Hasibuan (2011:12) definisi bank yaitu :

"Bank adalah lembaga keuangan, pencipta uang, pengumpul dana, pemberi kredit, mempermudah pembayaran dan penagihan, stabilisator moneter dan dinamisator perekonomian."

Fungsi bank adalah menghimpun dana dari masyarakat luas (funding) dan menyalurkan dana dalam bentuk pinjaman atau kredit (lending) untuk berbagai tujuan. Menurut Mudrajad Kuncoro (2011:166) fungsi utama bank adalah :

1. Menghimpun dana dari masyarakat dalam bentuk simpanan

2. Menyalurkan dana dalam bentuk kredit

3. Melancarkan transaksi perdagangan dan peredaran uang

Menurut Undang-Undang RI No. 10 Tahun 1998 tentang Perbankan bahwa jenis bank dapat ditinjau dari berbagai jenis, yaitu,

1. Bank Umum

Bank Umum adalah bank yang melaksanakan kegiatan usaha secara konvensional dan atau berdasarkan prinsip syariah yang dalam kegiatannya memberikan jasa dalam lalu lintas pembayaran.

2. Bank Perkreditan Rakyat (BPR)
Bank Perkreditan Rakyat adalah bank yang melakukan kegiatan usahanya secara konvensional atau berdasarkan prinsip syariah yang dalam kegiatannya tidak memberikan jasa dalam lalu lintas pembayaran.

Menurut Undang-Undang Republik Indonesia tentang Perbankan Syariah No. 21 Tahun 2008, nasabah adalah pihak yang menggunakan jasa bank syariah dan/atau UUS. Nasabah terbagi menjadi tiga kategori, yaitu nasabah penyimpan, nasabah investor dan nasabah penerima fasilitas.

Salah satu tujuan utama perusahaan khususnya perusahaan jasa dalam hal ini bank adalah menciptakan kepuasan pelanggan. Kepuasan pelanggan sebagai hasil penilaian pelanggan terhadap apa yang diharapkan dengan membeli dan mengkonsumsi suatu produk/jasa. Kemudian harapan tersebut dibandingkan dengan kinerja yang diterimanya dengan mengkonsumsi produk/jasa tersebut. Menurut Philip Kotler dan Kevin Lane Keller (2007:177) mengatakan bahwa kepuasan konsumen adalah perasaan senang atau kecewa seseorang yang muncul setelah membandingkan kinerja (hasil) produk yang dipikirkan terhadap kinerja yang diharapkan. Menurut Tjiptono (2012:301) kepuasan konsumen merupakan situasi yang ditunjukkan oleh konsumen ketika mereka menyadari bahwa kebutuhan dan keinginannya sesuai dengan apa yang diharapkan serta terpenuhi secara baik. Sedangkan menurut Djaslim (2003:9) pengertian kepuasan pelanggan adalah perasaan senang atau kecewa seseorang yang berasal dari perbandingan antara kesannya terhadap kinerja (hasil) suatu produk dan harapan-harapannya. Jadi, tingkat kepuasan adalah fungsi dari perbedaan antara kinerja yang dirasakan dengan harapan

Kepuasan pelanggan merupakan suatu tingkatan dimana kebutuhan, keinginan, dan harapan dari pelanggan dapat terpenuhi yang mengakibatkan terjadinya pembelian ulang atau kesetiaan yang berlanjut. Faktor yang paling penting untuk menciptakan kepuasan konsumen adalah kinerja dan kualitas dari layanan yang diberikan oleh organisasi.

Faktor-Faktor Yang Mempengaruhi Kepuasan Nasabah Penyimpan

Menurut Dahlan Siamat (1993:94) Daya tarik yang dapat diberikan kepada masyarakat atau nasabah dalam kegiatan penarikan dana dari masyarakat antara lain :

1. Ekspektasi (expectation), yaitu perkiraan keuntungan yang cukup bersaing dengan jenis 
investasi lainnya dengan tingkat risiko yang sama. Di bank dalam hal ini dapat dilihat dari pelayanan yang diberikan atau disediakan bank, yaitu dalam hal memberikan pelayanan baik dalam menghimpun dana ataupun dalam menyalurkan dana kepada nasabah yang membutuhkan.

Pelayanan disini menitikberatkan pada pelayanan dalam kegiatan penghimpunan dana yakni pelayanan yang diberikan kepada nasabah yang mempercayakan uangnya untuk disimpan di bank dengan suatu keuntungan atau manfaat yang dapat diperoleh kedua belah pihak tentunya. Keberhasilan pelayanan ini dapat dipengaruhi oleh unsur-unsur yang meliputi :

a. Tingkat bunga adalah jasa yang ditetapkan dan diberikan oleh bank terhadap simpanan nasabah

b. Hadiah adalah sesuatu yang dapat diberikan bertujuan untuk menarik calon nasabah untuk menabung di bank dengan melakukan undian bagi penyimpan yang jumlah tabungannya memenuhi ketentuan minimal.

2. Keamanan (safety) yaitu tingkat keamanan yang lebih terjamin oleh bank atas dana nasabah, bank harus bertanggung jawab atas keselamatan danadana dan menyediakan setiap saat jika diperlukan sesuai dengan klasifikasi simpanan tersebut. Keberhasilan faktor keamanan ini dapat dipengaruhi oleh unsur-unsur yang meliputi :

a. Dana tidak berkurang yaitu bahwa uang yang dipercayakan oleh para nasabah untuk disimpan dalam bentuk simpanan ini tidak mengalami pengurangan atau potongan apapun.

3. Ketepatan (accuracy) yaitu pengambilan atau penarikan dana yang tepat waktu atau ketetapan pelayanan baik dalam hal penarikan simpanan atau penarikan pinjaman, begitu pula dengan bank ketetapan pelayanan bank dalam memberikan pinjaman atau simpanan sampai uang diterima oleh nasabah. Hal ini dapat dipengaruhi oleh permodalan yang ada serta faktor kepercayaan manajer terhadap nasabah akan kemampuan untuk mengembalikan, hal ini meliputi :

a. Jumlah penarikan simpanan adalah ketepatan suatu bank dalam hal pemberian jumlah simpanan yang disediakan bank kepada nasabah. b. Waktu penarikan simpanan adalah ketentuan batasan atau waktu pemberian simpanan yang dijanjikan bank kepada nasabah.

c. Ketentuan batasan pengambilan adalah ketentuan batasan atau waktu minimal bagi nasabah untuk mengambil simpanannya dengan syarat-syarat tertentu.

4. Pelayanan (service) yaitu pelayanan yang lebih fleksibel dan cepat. Di bank dalam hal ini dapat dilihat kesediaan pihak bank dalam memberikan pelayanannya yang dapat meliputi :

a. Waktu kerja bank adalah pelayanan yang diberikan bank kepada nasabah dan hal waktu kerja pada karyawan untuk dapat melayani para nasabah.

b. Keberadaan karyawan di tempat kerja adalah pelayanan yang diberikan bank dalam hal kesediaan karyawan untuk melayani sepenuhnya nasabah yang akan melakukan simpanan.

c. Keramahan karyawan adalah pelayanan bank dilihat darikeramahan karyawan dalam melayani nasabah.

d. Kenyamanan ruangan adalah pelayanan yang diberikan dalam hal kenyamanan ruangan yang dimiliki oleh bank yang dapat menjadikan faktor pendukung nasabah untuk menyimpan uangnya di bank.

e. Jarak jangkauan pelayanan adalah pelayanan dari bank yang dilihat dari segui jarak jangkauan rumah nasabah ke bank yang menjadikan motivasi bagi nasabah untuk menyimpan uangnya di bank.

5. Pengelolaan dana oleh bank dilihat dari pembukuan yang dilakukan oleh manajemen bank, yaitu bahwa setiap transaksi yang terjadi dicatat dengan tepat dan sesuai dengan waktu terjadinya transaksi. Sebagai tambahan bank menghadapi kebutuhan yang harus dilakukan untuk nasabah berupa laporan berkala dari semua transaksi pada rekening nasabah. Bank harus bisa menangani fungsi-fungsi setoran dan pembayaran secara efisien, cepat dan waktu yang sama menjamin penyetor bahwa setiap transaksi yang mempengaruhi rekening. Penyetor akan dicatat secara pintas dilihat dari:

a. Buku tabungan yang dibuat sederhana adalah yang dilakukan oleh bank dalam hal pencatatan dalam bentuk buku tabungan nasabah yang menyimpan uang di bank.

b. Penyediaan dana adalah pengelolaan dana yang dilakukan oleh bank dalam hal 
penyediaan dana yang untuk berjaga -jaga apabila sewaktu-waktu nasabah akan menarik simpanannya.

Menurut Undang-Undang Republik Indonesia tentang Perbankan Syariah No 21 Tahun 2008, dana pihak ketiga adalah dana yang diperoleh dari masyarakat, dalam arti masyarakat sebagai individu, perusahaan, pemerintah, rumah tangga, koperasi, yayasan dan lain-lain dalam bentuk mata uang rupiah atau valuta asing (valas). Hal ini merupakan fungsi bank sebagai penghimpun dana dari masyarakat.

Dalam dunia perbankan, penghimpunan dana pihak ketiga/dana masyarakat dilakukan dengan cara menawarkan dan menjual produk penghimpunan dana yaitu :

1. Tabungan

Menurut Undang-Undang Republik Indonesia tentang Perbankan Syariah No 21 Tahun 2008, tabungan adalah simpanan berdasarkan akad wadiah atau investasi dana berdasarkan akad mudharabah atau akad lain yang tidak bertentangan dengan prinsip syariah yang penarikannya dapat dilakukan menurut syarat dan ketentuan tertentu yang disepakati, tetapi tidak dapat ditarik dengan cek, bilyet giro, dan/atau lainnya yang dipersamakan dengan itu.

2. Deposito

Menurut Undang-Undang Republik Indonesia tentang Perbankan Syariah No 21 Tahun 2008, deposito adalah investasi dana berdasarkan akad mudharabah atau akad lain yang tidak bertentangan dengan prinsip syariah yang penarikannya hanya dapat dilakukan pada waktu tertentu berdasarkan akad antara nasabah penyimpan dan Bank Syariah dan/atau UUS.

3. Giro

Menurut Undang-Undang Republik Indonesia tentang Perbankan Syariah No 21 Tahun 2008, Giro adalah simpanan berdasarkan akad wadiah atau akad lain yang tidak bertentangan dengan prinsip syariah yang penarikannya dapat dilakukan setiap saat dengan menggunakan cek, bilyet giro, sarana perintah pembayaran lainnya, atau dengan perintah pemindahbukuan.

\section{Financing to Deposit Ratio}

Dalam perbankan syariah tidak mengenal istilah kredit (loan) namun pembiayaan atau financing. Pada umumnya konsep yang sama ditunjukkan pada bank syariah dalam mengukur likuiditas yaitu dengan menggunakan Financing to Deposit Ratio
(FDR). Menurut Muhammad (2009:265) Financing to Deposit Ratio (FDR) yaitu seberapa besar Dana Pihak Ketiga (DPK) bank syariah dilepaskan untuk pembiayaan.

Rasio FDR dipergunakan untuk mengukur sejauh mana dana pinjaman berhasil dikerahkan oleh bank kepada nasabah peminjam yang bersumber dari dana pihak ketiga. Tinggi rendahnya rasio ini menunjukkan tingkat likuiditas bank tersebut. Sehingga semakin tinggi angka FDR suatu bank, berarti digambarkan sebagai bank kurang likuid dibanding dengan bank yang FDR nya lebih kecil.

Berdasarkan Surat Edaran Bank Indonesia No. 12/11/DPNF/2010 besarnya FDR ini ditetapkan oleh Bank Indonesia tidak boleh melebihi $110 \%$. Itu artinya bank boleh memberikan kredit atau pembiayaan melebihi jumlah dana pihak ketiga yang berhasil dihimpun asalkan tidak melebihi $110 \%$. Jadi, besarnya FDR yang diijinkan adalah $80 \%$ < FDR $<110 \%$, artinya minimum FDR adalah $80 \%$ dan maksimum FDR adalah $110 \%$. (A. Riawan Amin, 2009:41)

Berdasarkan Surat Edaran Bank Indonesia No. 9/24/DPBS tanggal 30 Oktober 2007, rasio FDR dirumuskan sebagai berikut :

$$
\mathrm{FDR}=\frac{\text { Pembiayaan yang diberikan }}{\text { Dana pihak ketiga }} \times 100 \%
$$

FDR dihitung dari perbandingan antara total pembiayaan yang diberikan bank dengan dana pihak ketiga. Dana pembiayaan adalah dana yang dibutuhkan untuk menggerakan sektor rill dan diharapkan untuk memicu pertumbuhan ekonomi. Begitu pula sebaliknya, bila dana bank tidak dapat disalurkan dengan baik maka dampaknya selain penggerakan sektor rill terhambat, juga mengakibatkan dana masyarakat tersebut menganggur dan dapat mempengaruhi berkurangnya uang beredar.

Financing to deposit ratio (FDR) menunjukkan sejauh mana kemampuan bank dalam membayar kembali penarikan dana yang telah dilakukannya kepada nasabah. Pembayaran yang dilakukan oleh bank kepada nasabah dilakukan untuk mengandalkan pembiayaan yang telah diberikan oleh bank tersebut. FDR ini digunakan untuk melihat seberapa jauh pembiayaan kepada nasabah dapat mengimbangi kewajiban untuk segera memenuhi hutang jangka pendeknya kepada nasabah yang ingin menarik kembali uangnya yang telah 
digunakan oleh bank untuk melihat kemampuan dan kerawanan dari suatu bank.

Financing to Deposit Ratio (FDR) dapat pula digunakan untuk menilai strategi suatu bank. Manajemen bank konservatif biasanya cenderung memiliki FDR yang relatif rendah. Sebaliknya bila FDR melebihi batas toleransi dapat dikatakan manajemen bank yang bersangkutan sangat ekspansif atau agresif (Siamat, 2001:32). Rasio ini juga digunakan untuk memberi isyarat apakah suatu pinjaman masih dapat mengalami ekspansif atau sebaliknya dibatasi. Jika bank memiliki FDR yang terlalu kecil maka bank akan kesulitan untuk menutup simpanan nasabah dengan jumlah pembiayaan yang ada. Jika bank memiliki FDR yang sangat tinggi maka bank akan mempunyai risiko tidak tertagihnya pinjaman yang tinggi dan pada titik tertentu bank akan mengalami kerugian. (Susilo, 1999:24)

Bank Pembiayaan Rakyat Syariah adalah bank yang kegiatan usahanya berdasarkan prinsip syariah dan dalam kegiatannya tidak memberikan jasa lalu lintas pembayaran. Sama seperti bank pada umumnya Bank Pembiayaan Rakyat Syariah melakukan kegiatan operasionalnya sebagai lembaga intermediasi antara pihak yang kelebihan dana dan pihak yang membutuhkan dana. Bank Pembiayaan Rakyat Syariah menjalankan kegiatan dalam penghimpunan dana (funding) dan penyaluran dana (lending). Dalam kegiatan penghimpunan dana (funding) dana yang dihimpun salah satunya berasal dari masyarakat yang menitipkan dananya di bank dalam bentuk tabungan dan deposito. Dana yang berasal dari masyarakat sering disebut dengan Dana Pihak Ketiga (DPK). Sedangkan dalam kegiatan penyaluran dana (lending) dana tersebut disalurkan dalam bentuk pembiayaan. Untuk mengukur sejauh mana dana pinjaman berhasil dikerahkan oleh bank yang bersumber dari dana pihak ketiga maka dapat di ukur dengan menggunakan Financing to Deposit Ratio (FDR). Tinggi rendahnya rasio ini menunjukkan tingkat likuiditas bank tersebut. Jadi semakin tinggi FDR nya maka bank tersebut kurang likuid dibandingkan dengan bank yang FDR nya lebih kecil. Besaran Financing to Deposit Ratio (FDR) yaitu $80 \%-110 \%$, FDR dihitung dari perbandingan antara total pembiayaan yang disalurkan dibagi dengan total Dana Pihak Ketiga yang dihimpun. FDR juga dapat digunakan untuk melihat seberapa jauh pembiayaan kepada nasabah dapat mengimbangi kewajiban untuk segera memenuhi hutang jangka pendeknya kepada nasabah yang ingin menarik kembali uangnya. Untuk mempertahankan besarnya FDR maka dilakukanlah upaya-upaya yaitu upaya intern dan upaya ekstern. Upaya intern merupakan upaya yang dilakukan oleh manajemen bank dalam kegiatan mobilisasi Dana Pihak Ketiga. Sedangkan, upaya ekstern merupakan upaya yang dilakukan dengan melakukan survey kepuasan nasabah.

\section{METODE PENELITIAN}

Metode yang digunakan ini adalah metode studi kasus (case study) yaitu dengan pengamatan langsung untuk mempelajari, memahami, serta menganalisis masalah yang telah didefinisikan dengan menggunakan pendekatan yang telah diuraikan dalam pendekatan masalah. Teknik pengambilan sampel yang digunakan adalah random sampling yaitu pengambilan sampel dengan cara acak. Sampel sebanyak 50 orang dari jumlah nasabah penyimpan 25.789 orang. Hal ini berdasarkan pada pendapat Sudjana (2005:28) yang menyatakan :

"Meskipun tidak ada kesepakatan untuk berapa $n$ sebuah sampel dikatakan berukuran besar, namun kebanyakan para pengguna statistik cenderung untuk merasa puas jika n sudah melampaui 30"

Instrumen pengukuran kuesioner menggunakan skala Likert, dengan kriteria :

a. Sangat puas $=5$

b. Puas = 4

c. Cukup puas $=3$

d. Tidak puas $=2$

e. Sangat Tidak puas $=1$

Penelitian ini pengukuran dengan menggunakan skala Likert, yaitu skala yang digunakan untuk mengukur sikap, pendapat, dan persepsi seseorang atau sekelompok orang tentang fenomena sosial. Dalam penelitian, fenomena sosial ini telah ditetapkan secara spesifik oleh peneliti, yang selanjutnya disebut dengan variabel penelitian. (Sugiyono, 2012:93)

\section{HASIL DAN PEMBAHASAN}

Pengukuran layanan kinerja bank dari sudut kepuasan nasabah dalam aktivitas penyimpanan dana di BPRS Al Ma'soem peneliti menggunakan beberapa faktor yang meliputi :

1. Ekspektasi (expectation)

2. Keamanan (safety)

3. Ketepatan (accuracy)

4. Pelayanan (service) 


\section{Pengelolaan dana}

Untuk melakukan penilaian terhadap faktorfaktor di atas, dengan menggunakan instrumen Kuisinoner Kepuasan Nasabah yang dibagikan kepada 50 orang nasabah penyimpan secara acak yang dijadikan sebagai sampel.

\section{Ekspektasi (expectation)}

Tabel 5. Rasio nisbah/bagi hasil

\begin{tabular}{lcccc}
\multicolumn{1}{c}{ Penilaian } & Skor & \multicolumn{2}{c}{ Responden } & Nilai \\
& & Orang & \% & Skor \\
Sangat puas & 5 & 16 & 32 & 80 \\
Puas & 4 & 27 & 54 & 108 \\
Cukup puas & 3 & 7 & 14 & 21 \\
Tidak puas & 2 & & & \\
Sangat tidak puas & 1 & & & \\
JUMLAH & & 50 & 100 & 209
\end{tabular}

Tabel 6. Hhdiah/bonus

\begin{tabular}{lcccc}
\hline \multicolumn{1}{c}{ Penilaian } & Skor & \multicolumn{2}{c}{ Responden } & Nilai \\
& & Orang & \% & \\
\hline Sangat puas & 5 & 14 & 28 & 70 \\
Puas & 4 & 31 & 62 & 124 \\
Cukup puas & 3 & 5 & 10 & 15 \\
Tidak puas & 2 & & & \\
Sangat tidak puas & 1 & & & \\
\hline JUMLAH & & 50 & 100 & 209 \\
\hline
\end{tabular}

Skor-skor yang diperoleh dari hasil data tersebut kemudian dimasukan kedalam tabel rekapitulasi penilaian sebagai berikut:

Tabel 7. Rekapitulasi hasil penilaian tentang ekspektasi

\begin{tabular}{clc}
\hline No & \multicolumn{1}{c}{ Indikator } & Skor \\
\hline 1 & Rasio nisbah/bagi hasil & 209 \\
2 & Bonus/hadiah & 209 \\
\hline & JUMLAH & $\mathbf{4 1 8}$ \\
\hline
\end{tabular}

Menentukan batas interval menggunakan rumus:

$$
I=\frac{(\operatorname{Skt} \times n \times J i)-(\operatorname{Skr} \times n \times J i)}{K}
$$

Keterangan :

I $=$ interval

Skt $=$ skor tertinggi

$\mathrm{Skr}=$ skor terendah

$\mathrm{K}=$ Jumlah Kriteria Penilaian

$\mathrm{Ji}=$ jumlah indikator

$\mathrm{n} \quad=$ jumlah sampel

Dari permasalahan diatas maka total skor yang diperoleh kemudian dikelompokan kedalam kriteria sebagai berikut:

$$
\mathrm{I}=\frac{(5 \times 50 \times 2)-(1 \times 50 \times 2)}{5}=80
$$

Sehingga kriteria penilaian adalah sebagai berikut :

Skor 50-129 : Artinya tingkat nasabah sangat tidak puas dengan ekspektasinya terhadap bank

Skor 130 - : Artinya tingkat nasabah tidak puas dengan

$209 \quad$ ekspektasinya terhadap bank

Skor 210 - : Artinya tingkat nasabah cukup puas

289 dengan ekspektasinya terhadap bank

Skor 290 - : Artinya tingkat nasabah puas dengan

$369 \quad$ ekspektasinya terhadap bank

Skor 370 - : Artinya tingkat nasabah sangat puas

450 dengan ekspektasinya terhadap bank

\section{Keamanan (safety)}

Tabel 8. Dana tidak berkurang

\begin{tabular}{lcccc}
\hline \multirow{2}{*}{ Penilaian } & \multirow{3}{*}{ Skor } & \multicolumn{2}{c}{ Responden } & \multirow{2}{*}{ Nilai Skor } \\
& & Orang & \% & \\
\hline Sangat puas & 5 & 22 & 44 & 110 \\
Puas & 4 & 20 & 40 & 80 \\
Cukup puas & 3 & 8 & 16 & 24 \\
Tidak puas & 2 & & & \\
Sangat tidak puas & 1 & & & \\
\hline JUMLAH & & 50 & 100 & 214 \\
\hline
\end{tabular}

Skor-skor yang diperoleh dari hasil data tersebut kemudian dimasukan kedalam tabel rekapitulasi penilaian sebagai berikut:

Tabel 9. rekapitulasi hasil penilaian tentang keamanan

\begin{tabular}{clc}
\hline No & \multicolumn{1}{c}{ Indikator } & Skor \\
1 & Dana tidak berkurang & 214 \\
& JUMLAH & $\mathbf{2 1 4}$ \\
\hline
\end{tabular}

Menentukan batas interval menggunakan rumus:

$$
\mathrm{I}=\frac{(\mathrm{Skt} \times \mathrm{n} \times \mathrm{Ji})-(\mathrm{Skr} \times \mathrm{n} \times \mathrm{Ji})}{\mathrm{K}}
$$

Keterangan :

$\mathrm{I}=$ interval

Skt $=$ skor tertinggi

$\mathrm{Skr}=$ skor terendah

$\mathrm{K}=$ Jumlah Kriteria Penilaian

$\mathrm{Ji}=$ jumlah indikator

$\mathrm{n} \quad=$ jumlah sampel

Dari permasalahan diatas maka total skor yang diperoleh kemudian dikelompokan kedalam kriteria sebagai berikut:

$$
\mathrm{I}=\frac{(5 \times 50 \times 1)-(1 \times 50 \times 1)}{5}=40
$$

Sehingga kriteria penilaian adalah sebagai berikut:

Skor 50-89 : Artinya nasabah sangat tidak puas dengan tingkat keamanan bank 
Skor 90-129 : Artinya nasabah tidak puas dengan tingkat keamanan bank

Skor 130-169 : Artinya nasabah cukup puas dengan tingkat keamanan bank

Skor 170-209 : Artinya nasabah puas dengan tingkat keamanan bank

Skor 210-250 : Artinya nasabah sangat puas dengan tingkat keamanan bank

\section{Ketepatan (accuracy)}

Tabel 10. Jumlah penarikan simpanan

\begin{tabular}{lcccc}
\hline \multirow{2}{*}{ Penilaian } & \multirow{2}{*}{ Skor } & \multicolumn{2}{c}{ Responden } & \multirow{2}{*}{ Nilai Skor } \\
\cline { 3 - 4 } & & Orang & \% & \\
\hline Sangat puas & 5 & 18 & 36 & 90 \\
Puas & 4 & 12 & 24 & 48 \\
Cukup puas & 3 & 20 & 40 & 60 \\
Tidak puas & 2 & & & \\
Sangat tidak puas & 1 & & & \\
JUMLAH & & 50 & 100 & 198 \\
\hline
\end{tabular}

Tabel 11. Waktu penarikan simpanan

\begin{tabular}{lcccc}
\hline \multirow{2}{*}{ Penilaian } & Skor & \multicolumn{2}{c}{ Responden } & \multirow{2}{*}{ Nilai Skor } \\
Sangat puas & 5 & 2 & 4 & 10 \\
Puas & 4 & 3 & 6 & 12 \\
Cukup puas & 3 & 45 & 90 & 135 \\
Tidak puas & 2 & & & \\
Sangat tidak puas & 1 & & & \\
JUMLAH & & 50 & 100 & 157 \\
\hline
\end{tabular}

Tabel 12. Ketentuan batasan penarikan simpanan

\begin{tabular}{|c|c|c|c|c|}
\hline \multirow{2}{*}{ Penilaian } & \multirow{2}{*}{ Skor } & \multicolumn{2}{|c|}{ Responden } & \multirow{2}{*}{ Nilai Sko } \\
\hline & & Orang & $\%$ & \\
\hline Sangat puas & 5 & 6 & 12 & 30 \\
\hline Puas & 4 & 8 & 16 & 32 \\
\hline Cukup puas & 3 & 36 & 72 & 108 \\
\hline Tidak puas & 2 & & & \\
\hline Sangat tidak puas & 1 & & & \\
\hline JUMLAH & & 50 & 100 & 170 \\
\hline
\end{tabular}

Skor-skor yang diperoleh dari hasil data tersebut kemudian dimasukkan kedalam tabel rekapitulasi penilaian sebagai berikut:

Tabel 4.9 rekapitulasi hasil penilaian tentang ketepatan

\begin{tabular}{clc}
\hline No & \multicolumn{1}{c}{ Indikator } & Skor \\
1 & Jumlah penarikan simpanan & 198 \\
2 & Waktu penarikan simpanan & 157 \\
3 & Ketentuan batasan penarikan simpanan & 170 \\
& JUMLAH & $\mathbf{5 2 5}$ \\
\hline
\end{tabular}

Menentukan batas interval menggunakan rumus:

$$
\mathrm{I}=\frac{(\mathrm{Skt} \times \mathrm{n} \times \mathrm{Ji})-(\mathrm{Skr} \times \mathrm{n} \times \mathrm{Ji})}{\mathrm{K}}
$$

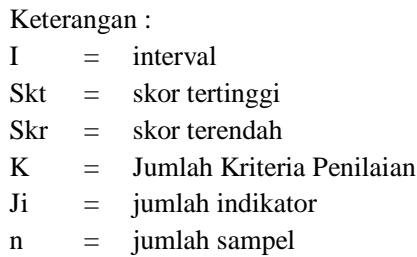

Dari permasalahan diatas maka total skor yang diperoleh kemudian dikelompokan kedalam kriteria sebagai berikut:

$$
\mathrm{I}=\frac{(5 \times 50 \times 3)-(1 \times 50 \times 3)}{5}=120
$$

Sehingga kriteria penilaian adalah sebagai berikut : Skor 50-169 : Artinya nasabah sangat tidak puas dengan tingkat ketepatan bank

Skor 170-289 : Artinya nasabah tidak puas dengan tingkat ketepatan bank

Skor 290-409 : Artinya nasabah cukup puas dengan tingkat ketepatan bank

Skor 410-529: Artinya nasabah puas dengan tingkat ketepatan bank

Skor 530-650 : Artinya nasabah sangat puas dengan tingkat ketepatan bank

Pelayanan (service)

\begin{tabular}{|c|c|c|c|c|}
\hline \multirow{2}{*}{ Penilaian } & \multirow{2}{*}{ Skor } & \multicolumn{2}{|c|}{ Responden } & \multirow{2}{*}{ Nilai Skor } \\
\hline & & Orang & $\%$ & \\
\hline Sangat puas & 5 & 12 & 24 & 60 \\
\hline Puas & 4 & 28 & 56 & 112 \\
\hline Cukup puas & 3 & 10 & 20 & 30 \\
\hline Tidak puas & 2 & & & \\
\hline Sangat tidak puas & 1 & & & \\
\hline JUMLAH & & 50 & 100 & 202 \\
\hline
\end{tabular}

Tabel 13. Waktu kerja

Tabel 14. Keberadaan karyawan di tempat kerja

\begin{tabular}{lcccc}
\hline Penilaian & Skor & \multicolumn{2}{c}{ Responden } & Nilai \\
& & Orang & \% & Skor \\
\hline Sangat puas & 5 & 16 & 32 & 80 \\
Puas & 4 & 27 & 54 & 108 \\
Cukup puas & 3 & 7 & 14 & 21 \\
Tidak puas & 2 & & & \\
Sangat tidak puas & 1 & & & \\
\hline JUMLAH & & 50 & 100 & 209 \\
\hline
\end{tabular}

Tabel 15. Keramahan karyawan

\begin{tabular}{lcccc}
\hline Penilaian & Skor & \multicolumn{2}{c}{ Responden } & Nilai \\
& & Orang & \% & Skor \\
\hline Sangat puas & 5 & 27 & 54 & 135 \\
Puas & 4 & 12 & 24 & 48 \\
Cukup puas & 3 & 11 & 22 & 33 \\
Tidak puas & 2 & & & \\
Sangat tidak puas & 1 & & & \\
\hline JUMLAH & & 50 & 100 & 216 \\
\hline
\end{tabular}


Tabel 16. Kenyamanan ruangan

\begin{tabular}{lcccc}
\hline \multirow{2}{*}{ Penilaian } & \multirow{2}{*}{ Skor } & \multicolumn{2}{c}{ Responden } & Nilai \\
& & Orang & \% & Skor \\
\hline Sangat puas & 5 & 19 & 38 & 95 \\
Puas & 4 & 23 & 46 & 92 \\
Cukup puas & 3 & 8 & 16 & 24 \\
Tidak puas & 2 & & & \\
Sangat tidak puas & 1 & & & \\
\hline JUMLAH & & 50 & 100 & 211 \\
\hline
\end{tabular}

Tabel 17. Jangkauan pelayanan

\begin{tabular}{lcccc}
\hline \multirow{2}{*}{ Penilaian } & \multirow{3}{*}{ Skor } & \multicolumn{2}{c}{ Responden } & Nilai \\
& & Orang & \% & Skor \\
\hline Sangat puas & 5 & 6 & 12 & 30 \\
Puas & 4 & 32 & 64 & 128 \\
Cukup puas & 3 & 12 & 24 & 36 \\
Tidak puas & 2 & & & \\
Sangat tidak puas & 1 & & & \\
\hline JUMLAH & & 50 & 100 & 194 \\
\hline
\end{tabular}

Skor-skor yang diperoleh dari hasil data tersebut kemudian dimasukkan kedalam tabel rekapitulasi penilaian sebagai berikut :

Tabel 18. Rekapitulasi hasil penilaian tentang pelayanan

\begin{tabular}{clc}
\hline No & \multicolumn{1}{c}{ Indikator } & Skor \\
\hline 1 & Waktu kerja & 202 \\
2 & Keberadaan karyawan di tempat kerja & 209 \\
3 & Keramahan karyawan & 216 \\
4 & Kenyamanan ruangan & 211 \\
5 & Jangkauan pelayanan & 194 \\
\hline & JUMLAH & $\mathbf{1 . 0 3 2}$ \\
\hline
\end{tabular}

Menentukan batas interval menggunakan rumus:

$$
\mathrm{I}=\frac{(\operatorname{Skt} \times n \times \mathrm{Ji})-(\operatorname{Skr} \times n \times \mathrm{Ji})}{K}
$$

Keterangan :

$\mathrm{I}=$ interval

Skt $=$ skor tertinggi

$\mathrm{Skr}=$ skor terendah

$\mathrm{K}=$ jumlah kriteria penilaian

$\mathrm{Ji}=$ jumlah indikator

$\mathrm{n} \quad=$ jumlah sampel

Dari permasalahan diatas maka total skor yang diperoleh kemudian dikelompokan kedalam kriteria sebagai berikut:

$$
\mathrm{I}=\frac{(5 \times 50 \times 5)-(1 \times 50 \times 5)}{5}=200
$$

Sehingga kriteria penilaian adalah sebagai berikut:

Skor $50-249$

: Artinya nasabah sangat tidak puas dengan tingkat pelayanan bank

Skor 250-449 : Artinya nasabah tidak puas dengan tingkat pelayanan bank

Skor 450-649 : Artinya nasabah cukup puas dengan tingkat pelayanan bank

Skor 650-849 : Artinya nasabah puas dengan tingkat pelayanan bank

Skor 850-1050 : Artinya nasabah sangat puas dengan tingkat pelayanan bank

\section{Pengelolaan Dana}

\begin{tabular}{|c|c|c|c|c|}
\hline \multirow{2}{*}{ Penilaian } & \multirow{2}{*}{ Skor } & \multicolumn{2}{|c|}{ Responden } & \multirow{2}{*}{$\begin{array}{l}\text { Nilai } \\
\text { Skor }\end{array}$} \\
\hline & & Orang & $\%$ & \\
\hline Sangat puas & 5 & 10 & 20 & 50 \\
\hline Puas & 4 & 34 & 68 & 136 \\
\hline Cukup puas & 3 & 6 & 12 & 18 \\
\hline Tidak puas & 2 & & & \\
\hline Sangat tidak puas & 1 & & & \\
\hline JUMLAH & & 50 & 100 & 204 \\
\hline
\end{tabular}

Tabel 19. Penyediaan dana

Tabel 20. Buku tabungan

\begin{tabular}{lcccc}
\hline Penilaian & Skor & \multicolumn{2}{c}{ Responden } & $\begin{array}{l}\text { Nilai } \\
\text { Skor }\end{array}$ \\
& & Orang & \% & \\
\hline Sangat puas & 5 & 18 & 36 & 90 \\
Puas & 4 & 27 & 54 & 108 \\
Cukup puas & 3 & 5 & 10 & 15 \\
Tidak puas & 2 & & & \\
Sangat tidak puas & 1 & & & \\
\hline JUMLAH & & $\mathbf{5 0}$ & $\mathbf{1 0 0}$ & $\mathbf{2 1 3}$ \\
\hline
\end{tabular}

Skor-skor yang diperoleh dari hasil data tersebut kemudian dimasukkan kedalam tabel rekapitulasi penilaian sebagai berikut:

Tabel 21. rekapitulasi hasil penilaian tentang pengelolaan

\begin{tabular}{clc}
\hline No & \multicolumn{1}{c}{ Indikator } & Skor \\
\hline 1 & Penyediaan dana & 204 \\
2 & Buku tabungan & 213 \\
\hline \multicolumn{2}{l}{ Jumlah } & $\mathbf{4 1 7}$ \\
\hline
\end{tabular}

Menentukan batas interval menggunakan rumus :

$$
\mathrm{I}=\frac{(\mathrm{Skt} \times \mathrm{n} \times \mathrm{Ji})-(\mathrm{Skr} \times \mathrm{n} \times \mathrm{Ji})}{\mathrm{K}}
$$

Keterangan :

I $=$ interval

Skt $=$ skor tertinggi

$\mathrm{Skr}=$ skor terendah

$\mathrm{K}=$ Jumlah Kriteria Penilaian

$\mathrm{Ji}=$ jumlah indikator

$\mathrm{n} \quad=$ jumlah sampel 
Dari permasalahan diatas maka total skor yang diperoleh kemudian dikelompokan kedalam kriteria sebagai berikut:

$$
I=\frac{(5 \times 50 \times 2)-(1 \times 50 \times 2)}{5}=80
$$

Sehingga kriteria penilaian adalah sebagai berikut:

Skor 50-129 : Artinya nasabah sangat tidak puas dengan tingkat pengelolaan dana bank

Skor 130-209 : Artinya nasabah tidak puas dengan tingkat pengelolaan dana bank

Skor 210-289 : Artinya nasabah cukup puas dengan tingkat pengelolaan dana bank

Skor 290-369 : Artinya nasabah puas dengan tingkat pengelolaan dana bank

Skor 370-450 : Artinya nasabah sangat puas dengan tingkat pengelolaan dana bank

Tabel 22. Rekapitulasi faktor-faktor yang mempengaruhi nasabah dalam menyimpan dana di BPRS Al Ma'soem

\begin{tabular}{clcc}
\hline No & \multicolumn{1}{c}{ Uraian } & Skor & Kriteria \\
\hline 1 & $\begin{array}{l}\text { Ekspektasi } \\
\text { (expectation) }\end{array}$ & 418 & Sangat puas \\
2 & Keamanan (safety) & 214 & Sangat puas \\
3 & Ketepatan (accuracy) & 525 & Puas \\
4 & Pelayanan (service) & 1032 & Sangat puas \\
5 & Pengelolaan dana & 417 & Sangat puas \\
\hline & Total skor & $\mathbf{2 . 6 0 6}$ & \\
\hline
\end{tabular}

Dari permasalahan diatas maka total skor yang diperoleh kemudian dikelompokan kedalam kriteria sebagai berikut:

$\frac{(5 \times 13 \times 50)-(1 \times 13 \times 50)}{5}$

$\frac{3250-650}{5}=\frac{2600}{5}=520$

Sehingga kriteria penilaian adalah sebagai berikut:

Skor $650-1170 \quad$ : Artinya nasabah sangat tidak puas dengan layanan bank

Skor $1171-1691$ : Artinya nasabah tidak puas dengan layanan bank

Skor $1692-2213$ : Artinya nasabah cukup puas dengan layanan bank

Skor $2214-2735$ : Artinya nasabah puas dengan tingkat layanan bank

Skor 2736 -- 3250 : Artinya nasabah sangat puas dengan layanan bank

Berdasarkan data rekapitulasi di atas, secara umum setiap faktor termasuk dalam kriteria sangat puas. Namun demikian terdapat satu faktor yang termasuk dalam kriteria puas yaitu pada faktor ketepatan (accuracy), hal ini biasanya disebabkan nasabah tidak dapat mengambil simpanannya setiap saat karena hanya dapat diambil ketika jam operasional bank. Dari tabel di atas diperoleh total skor 2.606 point, maka sesuai dengan skala nilai total faktor-faktor yang mempengaruhi nasabah dalam menyimpan dana di bank pada tabel 2.21 hasil yang peroleh termasuk kedalam kategori puas. Dengan demikian dapat disimpulkan bahwa masyarakat yang menjadi nasabah di BPRS Al Ma'soem sejauh ini menilai bahwa apa yang telah diberikan bank dengan saat ini nasabah sudah merasa puas, sehingga dapat memenuhi dan menampung setiap keinginan sekaligus memberikan kepuasan sesuai dengan yang diharapkan.

Dalam rangka meningkatkan penghimpunan Dana Pihak Ketiga (DPK) agar dapat menyeimbangi dana yang disalurkan kepada masyarakat. Salah satu cara untuk meningkatkan Dana Pihak Ketiga (DPK) yaitu dengan memberi kepuasan kepada nasabah. Berdasarkan hasil yang diperoleh pihak BPRS harus meningkatkan tingkat kepuasan nasabah dari "puas" menjadi "sangat puas".

Dilihat dari kondisi Financing to Deposit Ratio (FDR) pada 5 tahun terakhir secara rata-rata sebesar $114 \%$. Dan pada kondisi tahun terakhir yaitu tahun 2018 edisi maret besaran Financing to Deposit Ratio (FDR) yaitu 119,67\%, dengan jumlah pembiayaan yang disalurkan sebesar Rp. 141.603.408 dan dana pihak ketiga yang dihimpun sebesar Rp. 118.331.068, dikarenakan dana yang disalurkan lebih besar dibanding dana pihak ketiga yang dihimpun. Untuk mendapatkan besaran Financing to Deposit Ratio (FDR) yang ideal maka dana pihak ketiga harus ditambah sebesar $9,67 \%$ dari sebelumnya yaitu sebesar Rp. 11.442.614, maka dana pihak ketiga yang harus dihimpun yaitu sebesar Rp.

129.773.682.

$F D R=\frac{141.603 .408}{129.773 .682} \times 100 \%=109,115 \%$ maka kondisi Financing to Deposit Ratio (FDR) dalam kondisi ideal yaitu $109,115 \%$.

\section{KESIMPULAN DAN SARAN}

1. Secara umum setiap faktor termasuk dalam kriteria sangat puas. Namun demikian terdapat satu faktor yang termasuk dalam kriteria puas yaitu pada faktor ketepatan (accuracy), hal ini biasanya disebabkan nasabah tidak dapat mengambil simpanannya setiap saat karena hanya dapat diambil ketika jam operasional 
bank. Namun dengan demikian dapat disimpulkan bahwa masyarakat yang menjadi nasabah di BPRS Al Ma'soem sejauh ini menilai bahwa apa yang telah diberikan bank dengan saat ini nasabah sudah merasa puas, sehingga dapat memenuhi dan menampung setiap keinginan sekaligus memberikan kepuasan sesuai dengan yang mereka harapkan.

2. Upaya yang harus dilakukan oleh pihak bank (intern) untuk meningkatkan kegiatan mobilisasi dana pihak ketiga yaitu dengan melakukan upaya-upaya intern seperti meningkatkan kualitas pelayanan bank terhadap nasabah terutama dalam kegiatan penyimpanan dana dan manajemen pun harus lebih memprioritaskan kepuasan nasabah. Dengan demikian nasabah akan merasa puas dan akan lebih termotivasi untuk menyimpan dananya di BPRS Al Ma'soem, dan dampakanya kegiatan mobilisasi Dana Pihak Ketiga (DPK) akan terus meningkat.

3. Meningkatkan Dana Pihak Ketiga (DPK) yang dihimpun agar dapat menyeimbangi dana yang disalurkan kepada masyarakat. Salah satu cara untuk meningkatkan Dana Pihak Ketiga (DPK) yaitu dengan memberi kepuasan kepada nasabah. Berdasarkan hasil yang diperoleh pihak BPRS harus meningkatkan tingkat kepuasan nasabah dari "puas" menjadi "sangat puas". Dampaknya Dana Pihak Ketiga (DPK) mampu menyeimbangi dana yang disalurkan dan bank pun dapat mempertahankan kelikuiditasannya. Dana yang disalurkan harus diimbangi oleh dana pihak ketiga yang dihimpun agar kondisi Financing to Deposit Ratio (FDR) lebih ideal.

\subsection{Saran}

1. BPRS Al Ma'soem harus lebih memperhatikan dan ditingkatkan lagi keinginan dan kebutuhan nasabah maka nasabah akan lebih merasa sangat puas dengan apa yang disediakan oleh BPRS Al Ma'soem sendiri.

2. Dengan lebih diperhatikan dan ditingkatkan lagi keinginan dan kebutuhan nasabah maka akan berdampak pada kegiatan mobilisasi Dana Pihak Ketiga (DPK) yang dihimpun oleh BPRS Al Ma'soem.

3. Dana Pihak Ketiga (DPK) yang dihimpun harus lebih meningkat agar dapat menyeimbangi dana yang disalurkan kepada masyarakat. Dengan itu maka BPRS Al Ma'soem mampu mempertahankan kelikuiditasnnya.

\section{DAFTAR PUSTAKA}

Mundrajat Kuncoro dan Suhardjono. (2002). Manajemen Perbankan Teori dan Aplikasi, Yogyakarta: BPPE.

Muhammad Syafi'i. (2009). Manajemen Perbankan Syariah. Jakarta: Salemba Empat.

Rambai Lupiyadi. (2001). Manajemen Pemasran Jasa (Teori dan Praktek. Jakarta: Salemba Empat.

Sudjana. (2012). Metode Penelitian Kuantitatif, Kualitatif dan $R \& D$. Bandung: Alfabeta.

Fandy Tjiptono dan Gregorius Chandra. (2012). Pemasaran Strategik. Yogyakarta: Andi.

A. Riawan Amin. (2009). Menggagas Manajemen Syariah: Teori dan Prakti. Jakarta: Salemba Emapat.

Dahlan Siamat. (2005). Manajemen Bank Umum. Jakarta: Intermedia.

Djaslim Saladin. (2003). Intisari Pemasaran dan Unsur-Unsur Pemasaran. Bandung: Linda Karya.

Ramudi Arifin. (2003). Ekonomi Koperasi. Bandung: Ikopin.

Malayu Hasibuan. (2011). Dasar-Dasar Perbankan. Jakarta: PT. Bumi Aksara. 